\title{
EFFECT OF OXIDIZERS ON SULPHIDE REMOVAL FROM HAIR DISSOLVING LIMING WASTEWATER IN TANNERY
}

\author{
Md. Abul Hashem*, Mst. Nazmin Zaman Khan, Protima Roy, Md. Anik Hasan \\ Department of Leather Engineering, Khulna University of Engineering \& Technology (KUET), Khulna-9203, \\ Bangladesh
}

Received: 28 May 2021

Accepted: 12 November 2021

\begin{abstract}
Liming and unhairing is the conventional operation in the tannery where raw animal skins are treated with sodium sulphide and calcium hydroxide to remove keratin proteins e.g., hair and wool epidermis and to dissolve nonstructural proteins. The hair dissolving liming process discharges wastewater containing soluble sulphide. In acidification, the sulphide in wastewater generates toxic hydrogen sulphide, which has a negative impact on the environment. In this present study, the efficiency of hydrogen peroxide $\left(\mathrm{H}_{2} \mathrm{O}_{2}\right)$ and sodium chlorite $\left(\mathrm{NaClO}_{2}\right)$ oxidizers are compared to remove sulphide from the hair dissolving liming wastewater. The soluble sulphide in the raw liming wastewater was $3666 \mathrm{mg} / \mathrm{L}$. At optimized dose and $\mathrm{pH}$ for $\mathrm{H}_{2} \mathrm{O}_{2}$ and $\mathrm{NaClO}_{2}$ soluble sulphide in the solution were 109.2 and $54.6 \mathrm{mg} / \mathrm{L}$, respectively. The sulphide removal efficiency for $\mathrm{H}_{2} \mathrm{O}_{2}$ and $\mathrm{NaClO}_{2}$ were $97.0 \%$ and $98.5 \%$, respectively at an optimum $\mathrm{pH}(\mathrm{pH}$ 7). Before and after treatment the physicochemical parameters of the liming wastewater were analysed by observing different water quality parameters viz: $p H, T D S$, EC and salinity. At optimized condition TDS and salinity removal efficiency was $47.2 \%, 52.3 \%$ and $8.1 \%, 11.2 \%$ for $\mathrm{H}_{2} \mathrm{O}_{2}$ and $\mathrm{NaClO}_{2}$, respectively. This simple and easy method would be effective for treating hair dissolving liming wastewater in reducing soluble sulphide discharge from the tanneries.
\end{abstract}

Keywords:Tannery, Hair dissolving liming, Wastewater, Environment, Oxidizers

\section{INTRODUCTION}

The leather industry is considered one of the most potential sectors due to its enormous contributions to the world economy. In 2018, the leather industry contributes to the global market of US $\$ 80$ billion and it is expected to the US \$128 billion by 2022 (Sivaram \& Banik, 2019). Due to producing a large number of solids, liquids and gaseous pollutants, the leather industry is negatively criticised (Pal et al. 2020). The quantity and kind of pollutants generated during leather processing depend on mainly two factors i) processing technology and ii) chemicals (Souza \& Gutterres, 2012). On average every year, 15 million tons of hides and skins are processed which discharged more than 1500 million litres of wastewater (Rajamani et al. 2009). The discharged huge amount of wastewater accommodates a large number of different pollutants i.e. sodium, sulphide, chromium, chloride, nitrogen, total dissolved solids (TDS), biochemical oxygen demand (BOD), dyestuffs, and chemical oxygen demand (COD) (Chowdhury et al.2015). About $60-70 \%$ of pollutants of the leather industry are contributing from the unhairing and liming operation and this operation is considered as the highest pollution producing operation (Hashem et al. 2016). Besides dissolving the hair, wool, globulins, albumins, and subcutaneous layer, liming operation helps in swelling/plumping of the hide/skin and separating the non-structural proteins (Lofrano et al. 2013; Gutterres et al. 2011). The main chemicals used in the liming operation are lime $(\mathrm{CaO})$ and sodium sulphite $\left(\mathrm{Na}_{2} \mathrm{~S}\right)$. Although lime is responsible for the production of a huge volume of sludge, it does not create other serious environmental problems (Saravanabhavan et al. 2003). On the other hand, $\mathrm{Na}_{2} \mathrm{~S}$ is considered one of the most dangerous chemicals used in leather processing operations because upon acidification its turns into hazardous substances e.g., toxic hydrogen sulphide, $\mathrm{H}_{2} \mathrm{~S}$ gas (Dixit et al. 2015) as the below equation (i).

$$
\mathrm{S}^{2-}+\mathrm{H}^{+} \rightarrow \mathrm{H}_{2} \mathrm{~S} \text {.....(i) }
$$

The sources of sulphides in the liming wastewater are not only the $\mathrm{Na}_{2} \mathrm{~S}$ but also the sulphydryl $\left(\mathrm{SH}^{-}\right)$group present in hair, wool (Xu et al. 2009). The sulphur may present in the liming wastewater in two forms sulphides $\left(\mathrm{S}^{2-}\right)$ and sulphates $\left(\mathrm{SO}_{4}{ }^{2-}\right)$ (Souza \& Gutterres, 2012). When the $\mathrm{pH}$ of the liming wastewater goes down below 8 it produces $\mathrm{H}_{2} \mathrm{~S}$ which is treated as one of the most influencing hazardous gas (Rubright et al. 2017). Sulphide gas not only creates environmental problems but also affects human health adversely like headache, nausea, irritation of eyes, and unconsciousness (Selvaraj et al. 2020). Nuvolone et al. (2019) reported that a high concentration of $\mathrm{H}_{2} \mathrm{~S}$ is responsible for premature death. De Kok et al. (2009) have observed that an elevated amount of $\mathrm{H}_{2} \mathrm{~S}$ has 
an adverse effect on seed germination and plant growth. Therefore, sulphide containing liming wastewater or wastewater should be treated to minimize those problems.

Several researcher groups have been carried out to remove as well as recover sulphide from industrial wastewater. By using electrochemical process sulphide could be recovered from industrial mixed wastewater (Selvaraj et al. 2016). Liu \& Wang (2017) have observed that but using ionic liquid $100 \% \mathrm{H}_{2} \mathrm{~S}$ could remove from wastewater within 2 hours. Nanoporous carbon can remove sulphide from wastewater through adsorption mechanisms (Gholampour \& Yeganegi, 2014). Iron salts can remove sulphide from the municipal wastewater as ferrous sulphate by precipitation process (Zhang et al. 2008). Sergienko \& Radjenovic (2020) have usedmanganese oxidecoated electrodes to recover as well as remove sulphide from the wastewater. All these methods have some disadvantages like creating secondary pollutants, required high capital investment, and sophisticated equipment. The efficiency of the biological treatment process has also been investigated to remove sulphide from the wastewater. Kurt et al. (2007) have observed that the biological process is less effective compare to electrochemical oxidation processes. Recently oxidation process has gained much popularity to remove sulphide from different industrial wastewater e.g., sewer wastewater (El Brahmi \& Abderafi, 2021), petrochemical wastewater, and synthetic wastewater (Watsuntorn et al. 2019).In the present study, two oxidizers are used to remove sulphide from the hair dissolving liming wastewater of tannery.

The study aims to remove sulphide from the hair dissolving liming wastewater with low-cost oxidizers. The oxidizers hydrogen peroxide $\left(\mathrm{H}_{2} \mathrm{O}_{2}\right)$ and sodium chlorite $\left(\mathrm{NaClO}_{2}\right)$ are used to remove sulphide from the hair dissolving liming wastewater and compare their performance.

\section{METHODOLOGY}

\subsection{Sampling}

The hair dissolving liming wastewater was collected three times into 5-litre capacity high-density polyethylene (HDPE) bottle on September 15, 2019 from the Superex Leather Ltd. Khulna, Bangladesh. The samples were taken immediately to the laboratory for experimentation.

\subsection{Chemicals and Reagents}

The reagents hydrogen peroxide (50\%, TPL, Thailand), sodium chlorite (Hoechst, Switzerland), sulphuric acid (Merck, Germany), hydrochloric acid (Sigma Aldrich, Germany), potassium ferricyanide, barium chloride (UNICHEM, China), ammonium chloride (Loba Chemie, India), dimethyl glyoxime (Loba Chemie, India), iron(II) sulphate heptahydrate (Loba Chemie, India), ammonia solution (Loba Chemie, India), sulphuric acid (Merck Specialities Pvt. Ltd. India), ethanol (Merck KGaA, Germany) were purchased from a local scientific store, Khulna, Bangladesh. The buffer solution was prepared using $200 \mathrm{~g}$ ammonium chloride and $200 \mathrm{~g}$ ammonia solution per litre in deionized water. The indicator was prepared by mixing $10 \mathrm{~mL}$ of $0.6 \%$ ferrous ammonium sulphate, $50 \mathrm{~mL}$ of $1 \%$ dimethylglyoxime in ethanol and was acidified with $0.5 \mathrm{~mL}$ concentrated sulphuric acid. The barium chloride solution was prepared by dissolving $12.5 \mathrm{~g}$ barium chloride in $1000 \mathrm{~mL}$ deionized water. The titrant $0.1 \mathrm{~N}$ potassium ferricyanide was prepared by dissolving $32.925 \mathrm{~g}$ potassium ferricyanide in $1000 \mathrm{~mL}$ deionized water.

\subsection{Treatment of Hair Dissolving Liming Wastewater}

The hair dissolving liming wastewater was treated through the oxidation process. The preselected oxidizers $\mathrm{H}_{2} \mathrm{O}_{2}$ and $\mathrm{NaClO}_{2}$ were used in the oxidation process. Figure 1 depicts the scheme for the treatment process of liming wastewater.

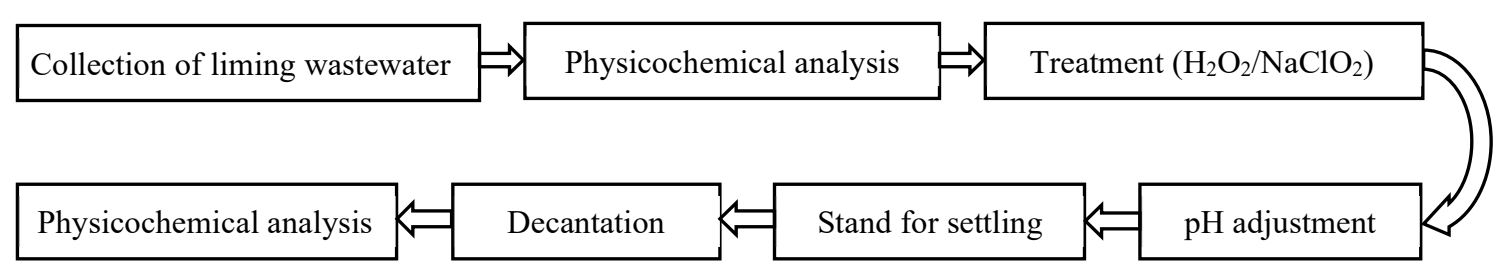

Figure 1: Scheme for the liming wastewater treatment process 
The physicochemical parameters of the raw liming wastewater such as $\mathrm{pH}$, total dissolved solids (TDS), soluble sulphide, salinity, and electrical conductivity (EC) were analysed. Then gradually preselected oxidizer $\left(\mathrm{H}_{2} \mathrm{O}_{2}\right.$ and $\left.\mathrm{NaClO}_{2}\right)$ was added with stirring at $150 \mathrm{rpm}$ to eliminate the generation of toxic hydrogen sulphide $\left(\mathrm{H}_{2} \mathrm{~S}\right)$ gas. The $\mathrm{pH}$ of the mixture was adjusted with the help of diluted hydrochloric acid and the mixture was stirred for an additional $5 \mathrm{~min}$ and kept for settling. Finally, soluble sulphide and physicochemical parameters of the treated wastewater were analysed.

\subsection{Analysis of Physicochemical Parameters}

The electrical conductivity (EC), total dissolved solids (TDS), and salinity were measured following the standard methods of APHA (APHA, 2012). The EC, TDS, salinity was measured using an ion meter (CT-676, BOECO, Germany). The $\mathrm{pH}$ of the solution was measured, using a pH meter (UPH-314, USA). Before measuring all the meters were calibrated using the standard solution. The sulphide was measured following the official method of SLC 202 (Society of Leather Technologist and Chemists, 1996).

\subsection{Measurement of Sulphide}

The raw liming wastewater and treated liming wastewater (section 2.3) with oxidizers were used for sulphide determination. A $25 \mathrm{~mL}$ wastewater was pipetted into a $200 \mathrm{~mL}$ Erlenmeyer flask where $10 \mathrm{~mL}$ buffer, $1 \mathrm{~mL}$ indicator, and $2.0 \mathrm{~mL}$ barium chloride were added and stoppered the flask. The flask was left for 1 min to precipitate the sulphite as barium sulphite to mask the interference. Finally, the solution was titrated with $0.1 \mathrm{~N}$ potassium ferricyanide until the pink colour was disappeared.

\subsection{Process Optimization}

Assessments were carried out to optimize the treatment parameters $\mathrm{pH}$ and oxidizers dose. For optimization of oxidizers $\left(\mathrm{H}_{2} \mathrm{O}_{2}\right.$ and $\left.\mathrm{NaClO}_{2}\right)$ dose, varying doses of $0.2,0.4,0.6,0.8,1.0$ and $1.2 \mathrm{~g}$ were used for batch treatment where other parameters remained unchanged. In the case of $\mathrm{pH}$ optimization, mildly acidic to mild alkali $\mathrm{pH}(6.0$, $6.5,7.0,7.5$, and 8.0) was investigated to obtain a higher sulphide removal efficacy.

\section{RESULTS AND DISCUSSION}

\subsection{Optimization of Oxidizers Dose}

Figure 2 illustrates the effect of oxidizers $\mathrm{H}_{2} \mathrm{O}_{2}$ and $\mathrm{NaClO}_{2}$ dose on the sulphide removal efficiency. The experiment was conducted with varying oxidizer doses $0.2,0.4,0.8,1.0$, and $1.2 \mathrm{~g}$ for $50 \mathrm{~mL}$ wastewater while the $\mathrm{pH}$ remained unchanged $(\mathrm{pH} 7)$. It seems that with increasing the oxidizer doses, the sulphide removal efficiency was increased. For $0.2 \mathrm{~g}$ oxidizer dose for $50 \mathrm{~mL}$ liming wastewater, sulphide removal efficiency for $\mathrm{H}_{2} \mathrm{O}_{2}$ and $\mathrm{NaClO}_{2}$ was $77.45 \%$ and $61.70 \%$, respectively. For both oxidizers with the increase of the doses the sulphide removal efficiency was proportionally increased. The possible explanation is that with the increase of the doses the number of active sites of the oxidants was increased that's why it can accommodate more sulphide from the wastewater (Edathil et al.2021).
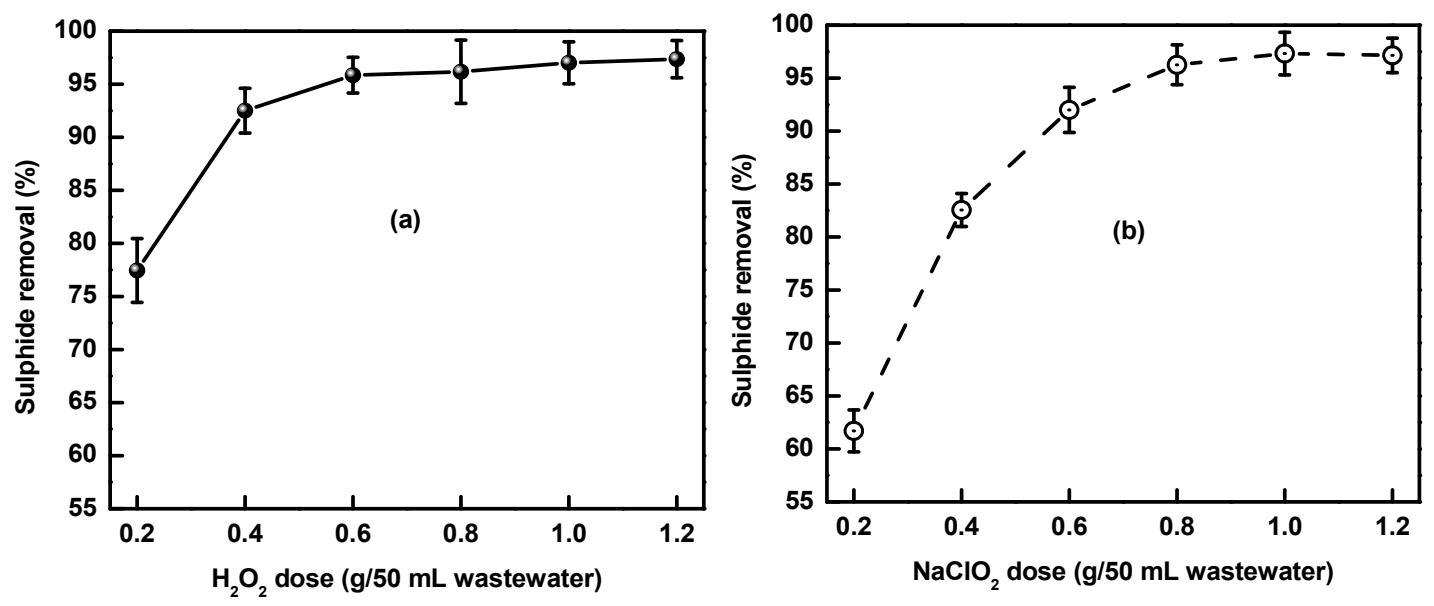

Figure 2: Oxidizers effect on sulphide removal a) $\mathrm{H}_{2} \mathrm{O}_{2}$ and b) $\mathrm{NaClO}_{2}$ 
It is clear from Figure 2(a) that sulphide removal efficiency was significantly increased for $\mathrm{H}_{2} \mathrm{O}_{2}$ dose from $0.2 \mathrm{~g}$ to $0.6 \mathrm{~g}$. Again, the $\mathrm{H}_{2} \mathrm{O}_{2}$ dose was gradually increased at $0.8,1.0$ and $1.2 \mathrm{~g}$ for $50 \mathrm{~mL}$ wastewater; sulphide removal percentage was insignificant. It is noticeable from Figure 2(b) that with increasing $\mathrm{NaClO}_{2}$ dose from 0.2 to $0.8 \mathrm{~g}$ for $50 \mathrm{~mL}$ wastewater; sulphide removal percentage was remarkably increased. In the case of increasing $\mathrm{NaClO}_{2}$ dose e.g., 1.0 and $1.2 \mathrm{~g}$ for $50 \mathrm{~mL}$ wastewater; the percentage of sulphide removal was not prominent. There is no significant difference in the removal of sulphide efficacy of the two oxidants. It is observable from Figure 2 that compares to $\mathrm{H}_{2} \mathrm{O}_{2} ; \mathrm{NaClO}_{2}$ has slight higher sulphide removal efficiency. $\mathrm{For}_{2} \mathrm{O}_{2}$ and $\mathrm{NaClO}_{2}$, the maximum sulphide removal efficiency was $97.4 \%$ and $97.3 \%$, which was achieved at a dose of $1.2 \mathrm{~g} / 50 \mathrm{~mL}$ and $1.0 \mathrm{~g} / 50 \mathrm{~mL}$, respectively.

\subsection{Optimum pH for Sulphide Removal}

According to Caliari et al. (2019), pH plays a vital role in the oxidation process. The effect of $\mathrm{pH}$ on the sulphide removal efficiency by two oxidizers $\left(\mathrm{H}_{2} \mathrm{O}_{2}\right.$ and $\left.\mathrm{NaClO}_{2}\right)$ was investigated and presented in Figure 3 . At the initial stage with an increase in the $\mathrm{pH}$, the percentage of sulphide removal was gradually increased for both the oxidizers. Above $\mathrm{pH} 7$, sulphide removal efficiency started to decrease.
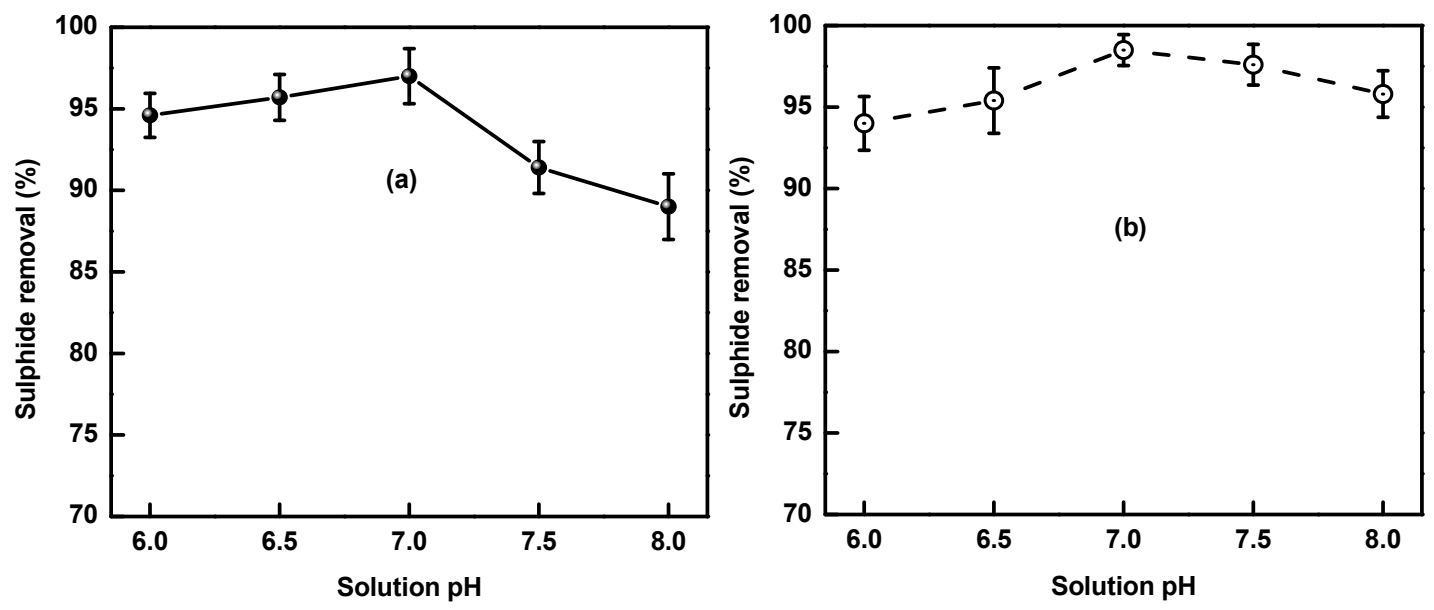

Figure 3: $\mathrm{pH}$ effect on sulphide removal a) $\mathrm{H}_{2} \mathrm{O}_{2}$ oxidizer b) $\mathrm{NaClO}_{2}$ oxidizer

For both oxidizers $\mathrm{H}_{2} \mathrm{O}_{2}$ and $\mathrm{NaClO}_{2}$, sulphide removal efficiency at neutral $\mathrm{pH}(\mathrm{pH} 7$ ) was $97.0 \%$ and $98.5 \%$, respectively. At $\mathrm{pH} 8.0$ for both oxidizers, gradually sulphide removal efficiency was decreased and was $89.0 \%$ and $98.8 \%$, respectively. The results indicate that sulphide may convert to hydrogen sulphide $\left(\mathrm{H}_{2} \mathrm{~S}\right)$ at lower $\mathrm{pH}$. However, the originated $\mathrm{H}^{+}$ion could be neutralized by the $\mathrm{OH}^{-}$at the higher $\mathrm{pH}$, which is mainly responsible for decreasing the $\mathrm{H}_{2} \mathrm{~S}$ formation and its removal from the solution (Saad et al. 2021). The same phenomena were observed in other studies (Wang et al. 2011; Dutta et al. 2008). Hence, the maximum sulphide removal efficiency was found at $\mathrm{pH} 7$ for both oxidizers, therefore, $\mathrm{pH} 7$ was chosen as an optimum $\mathrm{pH}$.

\subsection{Efficient Comparison of Oxidizers}

Before and after treatment the physicochemical parameters of the wastewater were assessed and the obtained results were compared with the standard as shown in Table 1. The physicochemical parameters of the raw liming wastewater were far above the standard. Except for electrical conductivity, all the parameters were reduced at a significant level after treating with $\mathrm{H}_{2} \mathrm{O}_{2}$ and $\mathrm{NaClO}_{2}$.

Table 1: Removal of pollution load from liming wastewater

\begin{tabular}{lccccc}
\hline \multirow{2}{*}{ Parameters } & \multirow{2}{*}{ Initial } & \multicolumn{2}{c}{ Treatment with } & \multirow{2}{*}{ ECR (1997) } & \multirow{2}{*}{ Unit } \\
\cline { 3 - 4 } & & $\mathbf{N a C l O}_{2}$ & $\mathbf{H}_{\mathbf{2}} \mathbf{O}_{2}$ & & \\
\hline $\mathrm{pH}$ & $12.3 \pm 0.04$ & $7.03 \pm 0.03$ & $7.0 \pm 0.02$ & $6-9$ & - \\
TDS & $16.3 \pm 0.04$ & $14.9 \pm 0.2$ & $8.6 \pm 0.06$ & 2.1 & $\mathrm{~g} / \mathrm{L}$ \\
Sulphide & $3666.01 \pm 9.3$ & $98.3 \pm 3.6$ & $109.2 \pm 4.2$ & 1.0 & $\mathrm{mg} / \mathrm{L}$ \\
EC & $33.8 \pm 0.07$ & $34.3 \pm 0.5$ & $19.8 \pm 0.06$ & 1.2 & $\mathrm{mS} / \mathrm{cm}$ \\
Salinity & $21.4 \pm 0.6$ & $19.0 \pm 0.4$ & $10.2 \pm 0.1$ & -- & $\mathrm{ppt}$ \\
\hline
\end{tabular}


In the case of sulphide removal, $\mathrm{NaClO}_{2}$ showed better results compare to $\mathrm{H}_{2} \mathrm{O}_{2}$ but for the other entire water quality parameters, $\mathrm{H}_{2} \mathrm{O}_{2}$ exhibit more superior results than $\mathrm{NaClO}_{2}$. The electrical conductivity of the $\mathrm{NaClO}_{2}$ treated wastewater was higher than the raw wastewater. This phenomenon was occurred due to the production of counter ion $\mathrm{Na}^{+}, \mathrm{H}^{+}, \mathrm{Cl}^{-}$while $\mathrm{NaClO}_{2}$ reacts with $\mathrm{HCl}$ (Trautmann et al. 2021). After treatment with $\mathrm{NaClO}_{2}$ and $\mathrm{H}_{2} \mathrm{O}_{2}$ the physicochemical parameters $\mathrm{pH}$, TDS, sulphide, EC, and salinity of the treated wastewater were: 7.03, $14.9 \mathrm{~g} / \mathrm{L}, 98.3 \mathrm{mg} / \mathrm{L}, 34.3 \mathrm{mS} / \mathrm{cm}, 19.0 \mathrm{ppt}$ and 7.00, $8.6 \mathrm{~g} / \mathrm{L}, 109.2 \mathrm{mg} / \mathrm{L}, 19.8 \mathrm{mS}, 10.2 \mathrm{ppt}$, respectively. Although in the treated wastewaters' TDS, sulphide and EC values were 4, 109, and 16 times higher than the acceptable limits of ECR (1997) which were much lower than the raw wastewater sample.

\section{CONCLUSIONS}

In the present study, the hair dissolving liming wastewater was treated with two common oxidants $\mathrm{H}_{2} \mathrm{O}_{2}$ and $\mathrm{NaClO}_{2}$. The performance of both the oxidants was compared by assessing the physicochemical parameters. The results revealed that in the case of sulphide removal $\mathrm{NaClO}_{2}$ showed better results than $\mathrm{H}_{2} \mathrm{O}_{2}$. The maximum sulphide removal was obtained at $\mathrm{pH}$ neutral $\mathrm{pH}$ (7) for both oxidizers. The $\mathrm{pH}$ was within the permissible level. The removal efficiency of sulphide, TDS, and salinity at optimized conditions for $\mathrm{H}_{2} \mathrm{O}_{2}$ and $\mathrm{NaClO}_{2} \mathrm{were} 97 \%$, $47.2 \%, 52.3 \%$ and $98.5 \%, 8.1 \%, 11.2 \%$, respectively. The EC was a little increased for $\mathrm{NaClO}_{2}$. The treated wastewater quality parameters indicate that both the oxidizer is effective in removing the pollution load parameters from hair dissolving liming wastewater. This investigation will help to treat sulphide-containing liming wastewater before discharging it into the environment.

\section{DECLARATION}

This is to declare that a part of this paper has been presented in ICCESD 2020 conference.

\section{REFERENCES}

APHA 2012. Standard methods for the examination of water and wastewater, 22nd Edn. American Public Health Association. American Water Works Association, Water Environment Federation, Washington DC.

Caliari P. C., Pacheco M. J., Ciríaco L., Lopes A., 2019. Tannery wastewater: Organic load and sulfide removal dynamics by electrochemical oxidation at different anode materials. Environ. Technol. Innov. doi:10.1016/j.eti.2019.100345

Chowdhury M., Mostafa M. G., Biswas T. K., Mandal A., Saha A. K., 2015. Characterization of the Effluents from Leather Processing Industries. Environ. Process. 2(1), 173-187

De Kok L. J., Yang L., Stuiver C. E. E., Stulen I., 2009. Chapter 5 Negative vs. Positive Functional Plant Responses to Air Pollution: A Study Establishing Cause-Effect Relationships of $\mathrm{SO}_{2}$ and $\mathrm{H}_{2} \mathrm{~S}$. Developments in Environmental Science. 121-135. doi:10.1016/s1474-8177(08)00205-2

Dixit S., Yadav A., Dwivedi P. D., Das M., 2015. Toxic hazards of leather industry and technologies to combat threat: A Review. J. Clean. Prod. 87, 39-49

Dutta P., Rabaeya K., Yuan Z., Keller J., 2008. Spontaneous electrochemical removal of aqueous sulfide. Water Res. 42(20), 4965-4975.

Edathil A. A., Kannan P., Haija M. A., Banat F., 2021. Sulfide remediation from wastewater using hydrothermally synthesized $\delta-\mathrm{MnO}_{2}$ /porous graphitic carbon as adsorbent. Environ. Res. doi:10.1016/j.envres.2020.110429

El Brahmi A., Abderafi S., 2021. Hydrogen sulfide removal from wastewater using hydrogen peroxide in-situ treatment: Case study of Moroccan urban sewers. Mater. Today: Proc. doi:10.1016/j.matpr.2021.01.641

Gholampour F., Yeganegi S., 2014. Molecular simulation study on the adsorption and separation of acidic gases in a model nanoporous carbon. Chem. Eng. Sci. 117, 426-435.

Gutterres M., Bordignon R. S., Baur L., 2011. Contamination of used soak/unhairing baths by nitrogen in comparison with carbon and soluble protein contents. J. Soc. Leather Technol. Chem. 95, 35-38.

Hashem M. A., Nur-A-Tomal M.S. Bushra S.A., 2016. Oxidation-coagulation-filtration processes for the reduction of sulfide from the hair burning liming wastewater in tannery. J. Clean. Prod. 127, 339-342.

Kurt U., Apaydin O., Gonullu M. T., 2007. Reduction of COD in wastewater from an organized tannery industrial region by Electro-Fenton process. J. Hazard. Mat. 143, 33-40.

Liu X., Li J., Wang R., 2017. Study on the desulfurization performance of hydramine/ionic liquid solutions at room temperature and atmospheric pressure. Fuel Process. Technol. 167, 382-387.

Lofrano G., Meriç S., Zengin G. E., Orhon D., 2013. Chemical and biological treatment technologies for leather tannery chemicals and wastewaters: A review. Sci. Total Environ. 461-462, 265-281.

Nuvolone D., Petri D., Pepe P., 2019. Health effects associated with chronic exposure to low-level hydrogen sulfide from geothermoelectric power plants. A residential cohort study in the geothermal area of Mt. Amiata in Tuscany. Sci. Total Environ. 659, 973-982. 
Pal M., Malhotra M., Mandal M. K., Paine T. K., Pal P., 2020. Recycling of wastewater from tannery industry through membrane-integrated hybrid treatment using a novel graphene oxide nanocomposite. J. Water Process. Eng. doi:10.1016/j.jwpe.2020.101324

Rajamani S., Chen Z., Zhang S., Su C., 2009. Recent Development in Cleaner Production and Environment Production in world Leather Sector. Proceedings of XXX IULTCS Congress, Beijing, China. 5.

Rubright S. L. M., Pearce L. L., Peterson J., 2017. Environmental toxicology of hydrogen sulfide. Nitric Oxide, $71,1-13$.

Saad E. G., Zewail T. M., Zatout A. A., El-Ashtoukhy E.-S. Z., Abdel-Aziz M. H., 2021. Electrochemical removal of sulfide ions and recovery of sulfur from sulfide ions containing wastes. J. Ind. Eng. Chem. 94, 390-396.

Saravanabhavan S., Aravindhan R., Thanikaivelan P., Rao J. R., Nair, B. U., 2003. Green solution for tannery pollution: effect of enzyme based lime-free unhairing and fibre opening in combination with pickle-free chrome tanning. Green Chem. 5, 707-714.

Selvaraj H., Aravind P., George H. S., Sundaram M., 2020. Removal of sulfide and recycling of recovered product from tannery lime wastewater using photoassisted-electrochemical oxidation process. J. Ind. Eng. Chem. 83, $164-172$.

Selvaraj H., Chandrasekaran K., Gopalkrishnan R., 2016. Recovery of solid sulfur from hydrogen sulfide gas by an electrochemical membrane cell. RSC Adv. 6(5), 3735-3741.

Sergienko N., Radjenovic J., 2020. Manganese oxide-based porous electrodes for rapid and selective (electro) catalytic removal and recovery of sulfide from wastewater. Appl. Catal B: Environ. doi:10.1016/j.apcatb.2020.118608

Sivaram N. M., Barik D., 2019. Toxic Waste from Leather Industries, Energy from Toxic Organic Waste for Heat and Power Generation, 55-67.

Society of Leather Technologists and Chemists (SLTC), 1996. Official Methods of Analysis: Northampton, UK.

Souza F. R., Gutterres M., 2012. Application of enzymes in leather processing: A comparison between chemical and co-enzymatic process. J. Chem. Eng. 29(3), 473-482.

Trautmann E., Attin T., Mohn D., Zehnder M., 2021. Hydrogen Peroxide Versus Sodium Hypochlorite: All a Matter of pH? J. Endod. 47(2), 297-302.

Wang Y., Li M., Feng C., Zhang Z., 2011. Electrochemical oxidation of sulfide in oil wastewater using Ti/Iro2anode. Environ. Prog. Sustain. Energy. 31(4), 500-506.

Watsuntorn W., Ruangchainikom C., Rene E. R., Lens P. N. L., Chulalaksananukul W., 2019. Comparison of sulphide and nitrate removal from synthetic wastewater by pure and mixed cultures of nitrate-reducing, sulphide-oxidizing bacteria. Bioresour. Technol. 272, 40-47.

Xu W., Zhang J., Hao L., 2009. Hair-saving enzyme- assisted unhairing effects of sodium hydrosulfide and peroxide. Proceedings of XXX IULTCS Congress. Beijing, China. 11-14.

Zhang L., De Schryver P., De Gusseme B., De Muynck W., Boon N., Verstraete W., 2008. Chemical and biological technologies for hydrogen sulfide emission control in sewer systems: A review. Water Res. 42(12), 1-12.

(C) 2021 the JES. Journal of Engineering Science published by Faculty of Civil Engineering, Khulna University of Engineering \& Technology. This is an open access article under the terms of the Creative Commons Attribution-NonCommercialNoDerivatives License, which permits use and distribution in any medium, provided the original work is properly cited, the use is non-commercial and no Modifications or adaptations are made. 